\title{
Tissue Response to a Membrane of Demineralized Bovine Cortical Bone Implanted in the Subcutaneous Tissue of Rats
}

\author{
Rodrigo Cardoso de OLIVEIRA ${ }^{1}$ \\ Renato MENEZES ${ }^{1}$ \\ Tânia Mary CESTARI ${ }^{2}$ \\ Eulázio Mikio TAGA ${ }^{2}$ \\ Rumio TAGA ${ }^{2}$ \\ Marília Afonso Rabelo BUZALAF ${ }^{2}$ \\ José Mauro GRANJEIRO ${ }^{2}$ \\ ${ }^{1}$ Department of Endodontics, and ${ }^{2}$ Department of Biological Sciences, \\ Bauru Dental School, University of São Paulo, Bauru, SP, Brazil
}

\begin{abstract}
The treatment of persistent bone defects has encouraged the search for proper techniques or bone substitutes. In Dentistry, a common problem in the treatment of periodontal bone defects is the growth of tissues within the lesion, such as the junctional epithelium, which impair regeneration of these tissues. Guided tissue regeneration (GTR), based on the separation of the tissues by means of membranes or barriers, was developed in an attempt to improve periodontal regeneration. The aim of this study was to histologically evaluate the tissue response to a membrane of demineralized bovine cortical bone implanted in the subcutaneous tissue of rats. The study periods were 1, 3, 7, 15, 30 and 60 days after implantation. Analysis of the histological sections demonstrated a moderate to intense inflammatory response at 1 and 3 days, moderate at 7 and 15 days, and almost absent at 30 and 60 days. Resorption of the membrane began 15 days after implantation, and at 60 days only remnants could be detected in some animals. We concluded that the demineralized bovine cortical bone membrane was well tolerated by the tissues and is completely resorbed after 30-60 days by mononuclear cells and multinucleated giant cells, which disappear upon completion of the process.
\end{abstract}

Key Words: GTR, barrier, biomaterials, absorbable membrane.

\section{INTRODUCTION}

Several aspects involved in bone regeneration have been studied. It is known that, despite its remarkable ability of spontaneous regeneration, the body response does not regenerate tissue in extensive bone defects, and therefore the application of a proper surgical technique or biomaterials is required.

The concept of anatomical sealing with a physical barrier to protect the clot and prevent the early invasion by adjacent tissues in the defect has been employed in Periodontology to allow regeneration of the entire supporting apparatus of the tooth. This surgi- cal technique is called guided tissue regeneration (GTR) (1). These principles were already employed in Medicine for the treatment of persistent extensive bone defects through the guided bone regeneration (GBR) technique. These two surgical techniques employ membranes or biological barriers, either resorbable or nonresorbable, to separate the adjacent tissues from the surgical site.

Despite the lack of clinical differences between the two types of membrane, the resorbable membranes eliminate a second surgery for removal of the nonresorbable membranes, providing shorter surgical time, better acceptance by the patient and reduced risk of loss

Correspondence: Prof. Dr. José Mauro Granjeiro, Departamento de Ciências Biológicas/Bioquímica, Faculdade de Odontologia de Bauru, Universidade de São Paulo, Al. Octávio Pinheiro Brisolla 9-75, 17012-901 Aeroporto, Bauru, SP, Brasil. Tel: +55-14-235-8246. Fax: +55-14-2262076. e-mail: jomagra@usp.br 
of the new insertion (2). Moreover, the possibility of associating growth factors to the resorbable membranes (3) has encouraged their utilization instead of the nonresorbable membranes.

The association of membranes to materials for bone graft has improved the clinical outcome, especially for the treatment of periodontal intraosseous defects, furcation lesions and dehiscences $(2,4)$.

Among the different types of resorbable membranes, collagen membranes have demonstrated excellent results, especially the membrane of demineralized bovine bone matrix, which is produced in Brazil and has been widely employed in dental clinics due to the accessible cost and proven clinical quality. However, despite the important role played by this type of membrane in bone surgeries, the biological events involved in the resorption of these membranes are not fully understood (5). The aim of this study was to evaluate the biocompatibility and resorption of a membrane of demineralized bovine cortical bone implanted in the subcutaneous tissue of rats.

\section{MATERIAL AND METHODS}

Sixty male rats (Rattus norvegicus), weighing about $250 \mathrm{~g}$, from the Central Animal Laboratory of Bauru Dental School - University of Sao Paulo, were randomly divided into groups of 10 animals according to the study periods. The study was carried out following the guidelines of the Ethics Committee for Teaching and Research in Animals of Bauru Dental School USP.

\section{Preparation of Animals and Procedures for Implantation}

The same surgical sequence was followed for all animals. The rats were anesthetized with an intramuscular injection of a mixture of ketamine/xylazine (Agribrands do Brasil Ltda, Paulinia, SP, Brazil) with a ratio of $1: 1(\mathrm{v} / \mathrm{v}), 0.5 \mathrm{~mL}$ per $\mathrm{kg}$ of weight. The dorsum of the animal, following the sagittal line, was submitted to trichotomy for exposure of the skin, followed by asepsis with gauze soaked in iodated alcohol. A straight incision was performed on the skin with a \#10 blade (Becton-Dickson, Sao Paulo, SP, Brazil) in laterolateral direction between the front legs of the animal, measuring approximately $1.5 \mathrm{~cm}$, which exposed the subcutaneous connective tissue. The margins of the incisions were then retracted and the connective tissue was dissected for placement of the membranes $\left(1 \mathrm{~cm}^{2}\right)$, previously hydrated with $0.9 \%$ sodium chloride solution. The membrane was produced with demineralized bovine cortical bone (Gen-derm ${ }^{\mathrm{TM}}$, Baumer S.A., Mogi Mirim, SP, Brazil, Registry in the Ministry of Health \#103.455.00007), sterilized with gamma radiation (25 $\mathrm{KG} \gamma$ ).

After membrane implantation, the margins of the wound were joined and closed with interrupted suture (4-0 silk sutures) for a perfect coaptation, distant from the material. Asepsis was performed again after suture. All animals received normal diet and water $a d$ libitum during the entire study period.

\section{Biopsy and Histotechnical Preparation}

The animals were anesthetized and a specimen of reaction tissue containing the material was removed at the study periods of $1,3,7,15,30$ and 60 days after implantation. Thereafter, the animals were sacrificed by cervical displacement, according to the guidelines of the Brazilian College of Animal Experimentation (COBEA). The biopsies were fixed in $10 \%$ formalin in phosphate buffer for 24 hours. After histotechnical processing, 6- $\mu \mathrm{m}$ thick alternate sections were taken and stained with hematoxylin-eosin.

\section{Histological Analysis}

The biological response was evaluated for inflammatory alterations (presence of edema, vascular alterations and inflammatory infiltrate) and the reparative process (degree of fibrosis, angioblastic and fibroblastic proliferation) of the tissues developed around the material.

\section{RESULTS}

The rats were healthy and did not present signs of edema, suppuration or exposure of the membrane during the entire postoperative period.

\section{Day}

The membrane was present and apparently intact in all animals of the sample. The inflammatory 
infiltrate was mild and comprised of mainly polymorphonuclear leukocytes (PMNs) and lymphocytes (Figure 1A). Some congested vessels were observed close to the membrane.

\section{Days}

The membrane was apparently intact in all specimens (Figure 1B). The inflammatory infiltrate was moderate to intense and comprised of PMNs and lymphocytes, revealing a larger number of blood vessels and capillaries around the membrane.

\section{Days}

The membrane was still apparently intact, however, with few sites of degradation (Figure 1C). The inflammatory infiltrate comprising PMNs and lymphocytes was intense, with a discrete degree of fibrosis and angioblastic proliferation. Angiogenesis in this period was remarkable in relation to the earlier periods. Giant cells were observed along the membrane, especially on the borders.
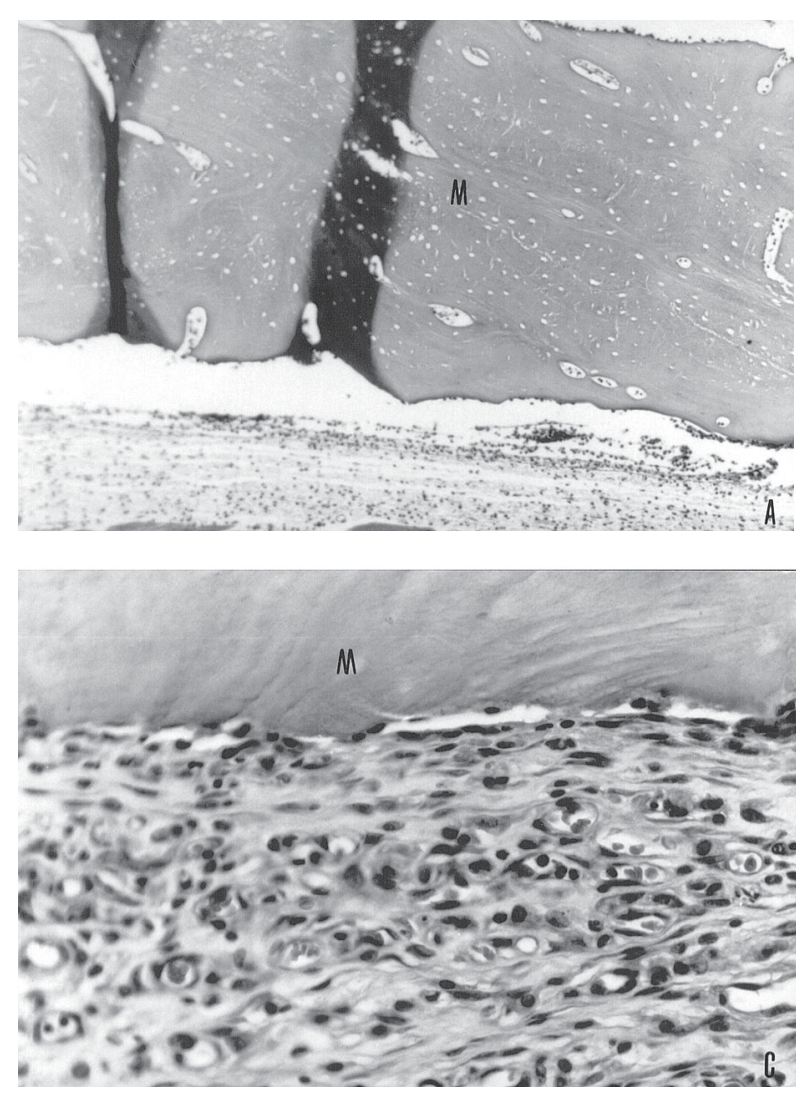

15 Days

Visible signs of membrane destruction were found in most samples, with intense destruction observed in one case (Figure 2A), and the membrane was almost intact in another. The presence of PMNs was mild, different from the larger degree of fibrosis, fibroblastic and angioblastic proliferation when compared to the previous periods. There was a considerable increase in the number of giant cells around the membrane in the entire sample.

\section{Days}

Only 4 samples showed membrane fragments in an advanced stage of degradation and in close contact with macrophages and giant cells (Figure 2B). The membranes had been completely resorbed and the tissue exhibited a normal aspect in six animals.

\section{Days}

The tissues were apparently normal in most ani-

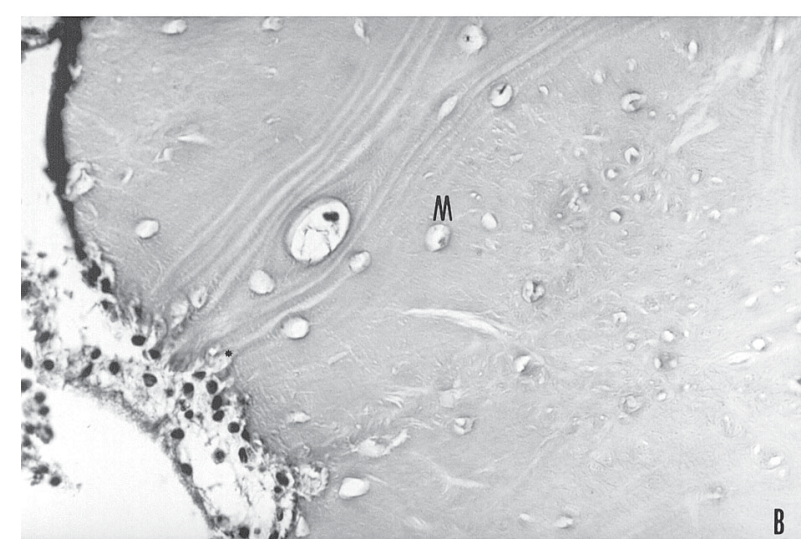

Figure 1. Photomicrographs of membrane implanted in subcutaneous rat tissue at 1 (A), 3 (B) and 7 (C) days. The membrane $(\mathrm{M})$ remained intact and surrounded by polymorphonuclear leukocytes. Few degradation sites (*, B) were observed in the membrane. The density of connective tissue around the membrane and the angiogenesis increased at 7 days (C). The membrane was circumscribed by macrophages and giant cells arising from surrounding tissues and many congested vessels (arrow). Original magnification: A 10X, B and C 40X; hematoxylin and eosin. 
mals (Figure 2C), with no signs of membrane, therefore suggesting complete resorption. Fragments of the membrane were observed in only 3 animals, surrounded by macrophages and giant cells and revealing a discrete fibrosis and presence of blood vessels.

\section{DISCUSSION}

Since the studies of Nyman et al. (1) on the efficiency of guided tissue regeneration for recovery of periodontal tissues, the search for improvement of this technique employing several types of membranes or biological barriers has been constant $(2,6,7)$. Resorbable materials are currently preferred to avoid the need of a second surgery, such as collagen-based membranes widely employed in GTR and guided bone regeneration (8-10). However, the cellular and molecular bases of the degradation of these membranes are not completely understood, and few studies are found concerning their pattern inside connective tissue (5).

The membrane of demineralized bovine cortical bone was obtained after organic solvents, peroxides and acid treatment of cortical bone and is mainly consti-
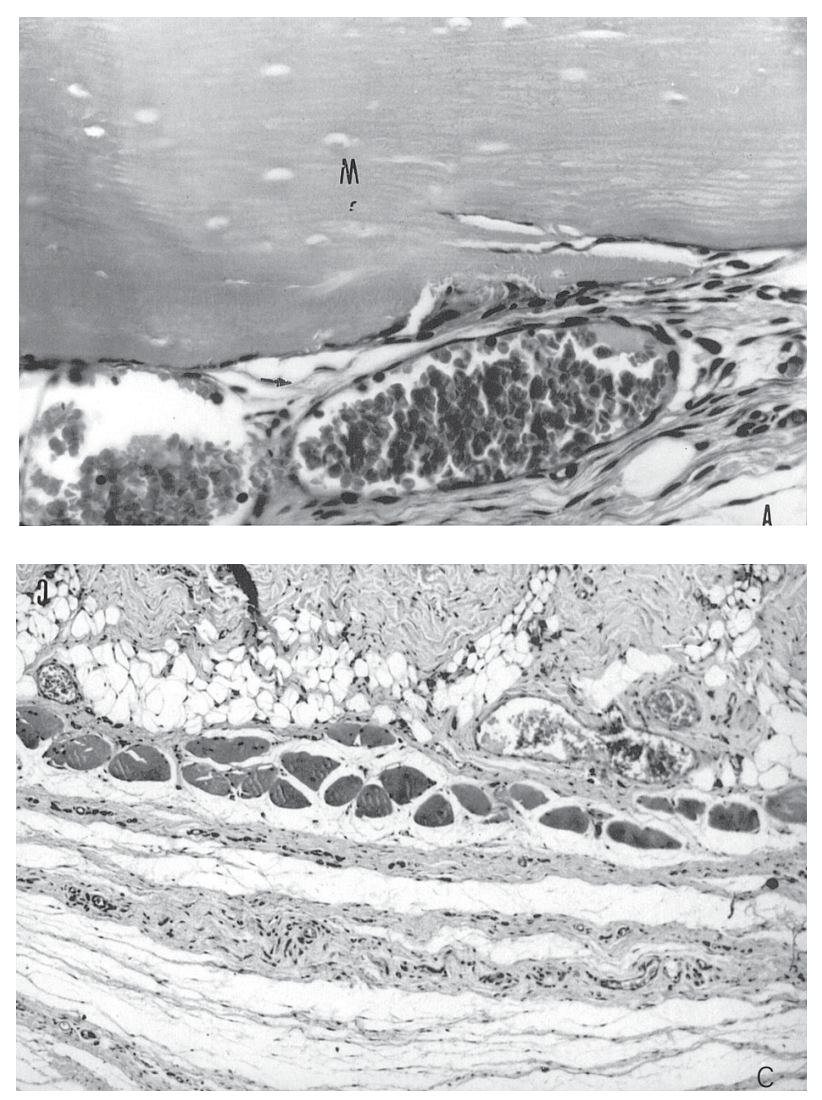

tuted by type I collagen and trace concentration of growth factors such as bone morphogenetic proteins. The present results demonstrated that this membrane is biocompatible, does not trigger the appearance of plasma cells or lymphocytes and is completely resorbed at 30 days. To play its role as a barrier, absorbable membranes should remain for at least three to four weeks (11). The membranes of demineralized bovine bone implanted in a subcutaneous pocket of rats were in an advanced stage of degradation after 30 days of surgery. Results from animal studies should be carefully analyzed when extrapolated to humans. However, under severe degradation conditions in subcutaneous tissue, the bovine membrane lasted for 3-4 weeks, suggesting its therapeutic potential.

Membranes of fibrillar type I collagen evaluated by other investigators (12) were not maintained for more than 30 to 45 days, being completely resorbed without inducing calcification. The utilization of human bone-derived membrane in GTR provided satisfactory clinical results when compared to the PTFE membrane. However, obtaining human bone is an important limiting factor, in addition to the need for a bone

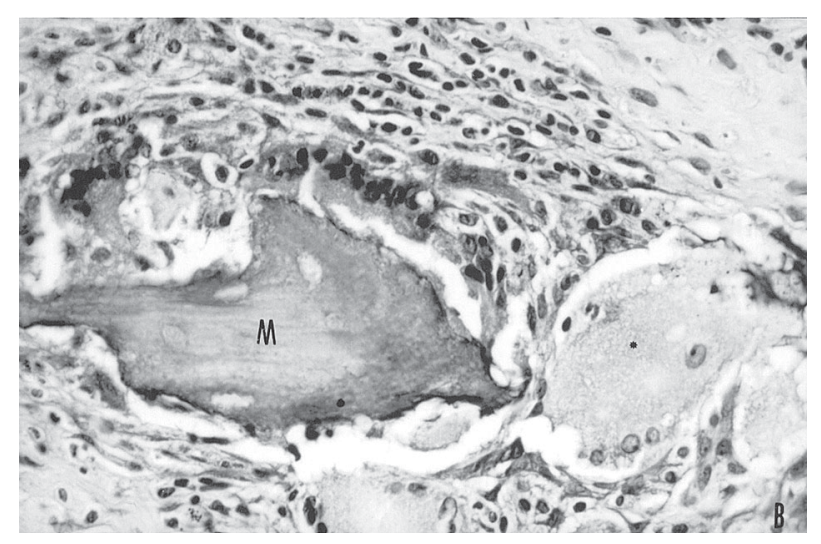

Figure 2. Photomicrographs of membrane (M) implanted in subcutaneous rat tissue at 15 (A), 30 (B) and 60 (C) days. Congested blood vessels were observed at 15 days (arrow, A). At 30 days, membrane fragments were observed circumscribed by giant cells $(*)$. No membrane fragments were observed in the normal subcutaneous tissue at 60 days $(C)$. Original magnification: $\mathrm{A}$ and B 40X, C 10X; hematoxylin and eosin. 
bank and the risk of disease transmission.

The degradation process comprised the recruitment of PMNs in the initial stage of acute inflammation. This stage is also related to surgical trauma. Both the inflammatory cells recruited for the tissue response and the angiogenesis surrounded the material, occasionally penetrating the interior of the membrane by means of gaps or pores. It should also be mentioned that no sign of tissue necrosis or the presence of immune cells were observed at any study period. This is an important aspect, since the absence of extreme inflammatory or immunological response to the material (13), which may impair the repair of the implanted area, are fundamental for GTR or GBR.

Currently, degradable membranes are commercially available in Brazil: Vycril (polyglactin), Resolut (polymer of lactic acid and glycolic acid) and BioGuide (bilayer of pig's peritoneum). Zhao et al. (14) examined the cellular response to these materials compared to the PTFE membrane (control) implanted in the subcutaneous tissue of rats. They observed that only the control was well tolerated and encapsulated by fibrous tissue. On the other hand, Vycril, Resolut and BioGuide membranes induced significant edema, encapsulation and an extensive inflammatory response. Vycril was stable, but induced an increase in the number of giant cells, whereas Resolut and Bio-Guide triggered a classical foreign body reaction up to 21 days.

Implantation of the demineralized bovine bone membrane demonstrated a completely different cell response. The giant cells disappeared with resorption of the material and tissue repair. The involvement of giant cells in the absorption of collagen without crosslinking has been reported $(5,12)$. Thus, these cells appear after the acute initial stage of the process, with participation of PMNs and lymphocytes. The reaction tissue is constituted mainly by giant cells and macrophages over time, which disappear after collagen degradation (12).

Implantation of the demineralized bovine bone membrane in bone defects yielded complete resorption of the membrane by means of a process mediated by mononuclear cells without any damage to the host tissue, purulent exudate or areas of necrosis $(15,16)$.

The subcutaneous or intramuscular implantation of devitalized and demineralized allogenic bone matrix may induce heterotopic osteogenesis (17). Even though the membrane employed in the present study was pro- duced from demineralized bone matrix, similar to the report of Urist et al. (18), the histological analysis did not reveal areas of osteogenesis during the entire stage of membrane resorption.

The nature of the inflammatory multinucleated giant cells (IMGCs) recruited in subcutaneous grafts of mineralized materials, including allogenic bone, is still controversial. However, particles of thermally deproteinized inorganic bone (natural hydroxyapatite) have been demonstrated to induce a chronic inflammatory reaction with the presence of giant cells and fibrosis of the particles in the subcutaneous tissue of rats (19). Therefore, it is reasonable to suggest that the recruitment of giant cells may be related to the persistence of remnants of the mineral phase on the membrane.

However, according to Kelly and Schneider (20), this type of response does not necessarily indicate disqualification of the material. These investigators implanted demineralized and mineralized allogenic matrixes and a combination of both on a dorsal subcutaneous area of young adult rats and observed the presence of multinucleated giant cells on the mineralized implants that were not morphologically similar to osteoclasts. In the implant of demineralized matrix, the morphology of most giant cells was similar to osteoclasts, whereas the combined implantation revealed the presence of both types of multinucleated giant cells.

The presence of calcium in the material, which activates the recruitment of multinucleated giant cells, may be an additional element in the speed of degradation of the membrane. This pointed out the need for further studies in order to define the real participation of calcium on the cell response to this membrane.

The present results allowed to conclude that the membrane of demineralized bovine cortical bone is well tolerated by the tissues, being completely resorbed at 30-60 days by mononuclear cells and multinucleated giant cells that disappeared at completion of the process. The absorbable membrane derived from bovine cortical bones could be used as a barrier to promote tissue regeneration in surgical techniques of guided tissue regeneration, but further in vivo and clinical studies should be conduced in order to determine the clinical efficacy of this membrane.

\section{RESUMO}

O tratamento de defeitos ósseos perenes tem motivado a busca 
por técnicas ou substitutos ósseos adequados. Na odontologia, um problema comum no tratamento de defeitos ósseos periodontais é o crescimento de tecidos competidores para o interior da lesão, como o epitélio juncional da gengiva, prejudicando a regeneração desses tecidos. Buscando melhorar a regeneração periodontal foi desenvolvida a técnica da Regeneração Tecidual Guiada (RTG) baseada na separação dos tecidos através de membranas ou barreiras. Objetivo deste estudo foi avaliar histologicamente a resposta tecidual à membrana obtida do osso cortical bovino desmineralizado, implantada em subcutâneo de ratos. Os períodos analisados foram de 1, 3, 7, 15, 30 e 60 dias após a implantação. A análise dos cortes histológicos mostrou resposta inflamatória de moderada a intensa nos períodos de $1 \mathrm{e}$ 3 dias, moderada aos 7 e 15 dias, e praticamente inexistente aos 30 e 60 dias. A reabsorção da membrana se iniciou 15 dias pósimplantação e ao final de 60 dias apenas resquícios foram detectados em alguns animais. Concluímos que a membrana derivada do osso cortical bovino desmineralizado é bem tolerada pelos tecidos sendo completamente reabsorvida após 30-60 dias por células mononucleadas e células gigantes multinucleadas que desaparecem ao final do processo.

\section{ACKNOWLEDEGMENTS}

The authors are very grateful to Thelma L. da Silva, Ovídio dos Santos Sobrinho, Gilmar V. da Silva, Pâmela R.A. Leoni, Luiz C. da Silva, Erasmo G. da Silva, and Daniele S. Ceolin for skillfull technical assistance. This study was supported by Fundação de Amparo à Pesquisa do Estado de São Paulo, Conselho Nacional de Desenvolvimento Científico e Tecnológico (R.C.O. fellowship), Coordenação de Aperfeiçoamento de Pessoal de Nível Superior, and the University of São Paulo.

\section{REFERENCES}

1. Nyman S, Lindhe J, Karring T, Rylander H. New attachment following surgical treatment of human periodontal disease. J Clin Periodontol 1982;9:290-296.

2. Wang HL, Macneil RL. Guided tissue regeneration. Absorbable barriers. Dent Clin N Am 1998;42:505-522.

3. Chen CC, Wang HL, Lopatin DE, O'Neal RB, Macneil RL. Bacterial adherence to guided tissue regeneration barrier membranes exposed to the oral environment. J Periodontol 1997;68:172-179.

4. Bunyaratavej P, Wang HL. Collagen membranes: A review. J Periodontol 2001;72:215-229.

5. Galgut P, Pitrola R, Waite I, Doyle C, Smith R. Histological evaluation of biodegradable and non-degradable membranes placed transcutaneously in rats. J Clin Periodontol 1991;18:581586.

6. Blumenthal NM. A clinical comparison of collagen membranes with ePTFE membranes in the treatment of human mandibular buccal class II furcation defects. J Periodontol 1993;64:925-933.

7. Novaes Junior AB, Novaes AB. Guided tissue regeneration versus hemisection in the treatment of furcation lesions. A clinical analysis. Braz Dent J 1993;3:99-102.

8. Nociti Junior FH, Caffesse RG, Sallum EA, Machado MA, Stefani $\mathrm{CM}$, Sallum AW. Clinical study of guided bone regeneration and/ or bone grafts in the treatment of ligature-induced peri-implantitis defects in dogs. Braz Dent J 2001;12:127-131.

9. Oh TJ, Meraw SJ, Lee EJ, Giannobile WV, Wang HL. Comparative analysis of collagen membranes for the treatment of implant dehiscence defects. Clin Oral Impl Res 2003;14:80-90.

10. Dietrich T, Zunker P, Dietrich D, Bernimoulin JP. Periapical and periodontal healing after osseous grafting and guided tissue regeneration treatment of apicomarginal defects in periradicular surgery: Results after 12 months. Oral Surg Oral Med Oral Path Oral Radiol Endod 2003;95:474-482.

11. Minabe M. Selective periodontal tissue reconstruction therapy. J Periodontol 1991;62:171-179.

12. Boon ME, Ruijgrok JM, Vardaxis MJ. Collagen implants remain supple not allowing fibroblast ingrowth. Biomaterials 1995;16:1089-1093.

13. Holland R, de Souza V, Nery MJ, Faraco Junior IM, Bernabe PF, Otoboni Filho JA, Dezan Junior E. Reaction of rat connective tissue to implanted dentin tube filled with mineral trioxide aggregate, Portland cement or calcium hydroxide. Braz Dent J 2001;12:3-8.

14. Zhao S, Pinholt EM, Madsen JE, Donath K. Histological evaluation of different biodegradable and non-biodegradable membranes implanted subcutaneously in rats. J Cranio-Maxillofacial Surg 2000;2000:116-122.

15. Taga R, Hassunuma CY, Cestari TM, Ferreira PM. Destino de membrana de cortical óssea bovina colocada em posição subperiostica na calvária de cobaia. Rev Bras Implant 1997;5:2429.

16. Benoit Núñez JS. Análise histológica da reabsorção e da biocompatibilidade de membrana de cortical óssea bovina colocada sobre calvária de cobaia decorticada. [Master's Thesis]. Bauru: Faculdade de Odontologia de Bauru, Universidade de São Paulo; 1999. 100p

17. Reddi AH, Huggins C. Biochemical sequences in the transformation of normal fibroblasts in adolescent rats. Proc Natl Acad Sci USA 1972;69:1601-1605.

18. Urist MR. Bone: formation by autoinduction. Science 1965;150:893-899.

19. Oliveira RC, Sicca CM, Silva TL, Cestari TM, Oliveira DT, Buzalaf MAR, Taga R, Taga EM, Granjeiro JM. Efeito da temperatura de desproteinização no preparo de osso cortical bovino microgranular. Avaliação microscópica e bioquímica da resposta celular em subcutâneo de ratos. Rev FOB 1999;7:85-93.

20. Kelly JD, Schneider GB. Morphological and histochemical comparison of cells elicited by ectopic bone implants and tibial osteoclasts. Am J Anat 1991;192:45-54. 